\title{
Dysregulation of protein trafficking in neurodegeneration
}

\author{
Xin Wang ${ }^{1,2}$, Timothy Huang ${ }^{2}$, Guojun Bu ${ }^{1}$ and Huaxi $\mathrm{Xu}^{1,2^{*}}$
}

\begin{abstract}
Intracellular protein trafficking plays an important role in neuronal function and survival. Protein misfolding is a common theme found in many neurodegenerative diseases, and intracellular trafficking machinery contributes to the pathological accumulation and clearance of misfolded proteins. Although neurodegenerative diseases exhibit distinct pathological features, abnormal endocytic trafficking is apparent in several neurodegenerative diseases, such as Alzheimer's disease (AD), Down syndrome (DS) and Parkinson's disease (PD). In this review, we will focus on protein sorting defects in three major neurodegenerative diseases, including AD, DS and PD. An important pathological feature of $A D$ is the presence of extracellular senile plaques in the brain. Senile plaques are composed of $\beta$-amyloid (A $\beta$ ) peptide aggregates. Multiple lines of evidence demonstrate that over-production/aggregation of $A \beta$ in the brain is a primary cause of $A D$ and attenuation of $A \beta$ generation has become a topic of extreme interest in $A D$ research. $A \beta$ is generated from $\beta$-amyloid precursor protein (APP) through sequential cleavage by $\beta$-secretase and the $\gamma$-secretase complex. Alternatively, APP can be cleaved by a-secretase within the A $\beta$ domain to release soluble APPa which precludes $A \beta$ generation. DS patients display a strikingly similar pathology to AD patients, including the generation of neuronal amyloid plaques. Moreover, all DS patients develop an AD-like neuropathology by their $40 \mathrm{~s}$. Therefore, understanding the metabolism/processing of APP and how these underlying mechanisms may be pathologically compromised is crucial for future AD and DS therapeutic strategies. Evidence accumulated thus far reveals that synaptic vesicle regulation, endocytic trafficking, and lysosome-mediated autophagy are involved in increased susceptibility to PD. Here we review current knowledge of endosomal trafficking regulation in AD, DS and PD.
\end{abstract}

Keywords: $\beta$-amyloid precursor protein, $\beta$-secretase, $\gamma$-secretase, Sorting nexin, The retromer complex, Ras-related GTP-binding protein, Alzheimer's disease, Down syndrome, Parkinson's disease, Endocytic trafficking

\section{Background}

Endocytic dysregulation is apparent in many neurodegenerative diseases, including Alzheimer's disease (AD), Parkinson's disease (PD) and Down syndrome (DS) as key examples. $\mathrm{AD}$ is the most common form of agedependent neurodegeneration, affecting about $10 \%$ of the population over the age of 65 and about $50 \%$ of the population over the age of 85 . Only a small subset $(<10 \%)$ of $\mathrm{AD}$ cases is caused by inherited autosomal dominant gene mutation, and most of these familial $\mathrm{AD}$ mutations are found in genes encoding $\beta$-amyloid precursor protein (APP) and presenilins (PS1 and PS2)

\footnotetext{
* Correspondence: xuh@sanfordburnham.org

${ }^{1}$ Fujian Provincial Key Laboratory of Neurodegenerative Disease and Aging Research, Institute of Neuroscience, College of Medicine, Xiamen University, Xiamen, Fujian 361102, China

${ }^{2}$ Degenerative Disease Research Program, Sanford-Burnham Medical Research Institute, La Jolla, California 92037, USA
}

[1-4]. Accumulation of two AD hallmarks has been found in the hippocampus and cortex of AD brain, including extracellular neuritic plaques and intracellular neurofibrillary tangles (NFTs). NFTs comprise hyperphosphorylated filaments of the microtubule-associated protein tau [5]. Neuritic plaques are composed of $\beta$-amyloid $(A \beta)$ generated through sequential proteolytic cleavage of the $\beta$-amyloid precursor protein (APP) by $\beta$ - and $\gamma$ secretases [6]. APP can also be cleaved by $\alpha$-secretase which cuts within the $A \beta$ domain to preclude $A \beta$ generation. $\alpha$-secretase processing generates a secreted form of APP with neuroprotective properties. Accumulated evidence support that subcellular localization and trafficking of APP and its proteolytic secretases is critical for $A \beta$ production. BACE1-mediated APP cleavage constitutes the rate-limiting step in $A \beta$ generation [7]. It has been reported that BACE1 is up-regulated in human AD 
brain [8] and altered intracellular trafficking of BACE1 is involved in AD pathology [9-12]. A previous study suggested a mechanism for BACE1 elevation in AD where BACE1 is normally transported to lysosomes by GGA3, whereby caspase-mediated GGA3 cleavage prevents BACE1 degradation [13]. BACE1 is primarily localized in the trans-Golgi network (TGN) and endosomes [14], which are major cellular sites for $\beta$-secretase activity with an optimal $\mathrm{pH}$ value [15]. Furthermore, BACE1 is rapidly internalized from the cell surface [16] and transported to early endosomes where internalized BACE1 can be recycled by the retromer complex [17-19]. Deficiency in endocytic and recycling components will result in abnormal BACE1 trafficking and $\beta$-secretase activity. Low-density lipoprotein receptor-related proteins 1 (LRP1) is a type-I transmembrane glycoprotein. It has been demonstrated that LRP1 can affect APP trafficking and processing through APP binding interactions with LRP1 extracellular and intracellular domains [20-22]. Further understanding of AD-related protein trafficking and regulation would provide new approaches for AD therapy.

Down syndrome (DS) is a congenital disorder that affects multiple organs and causes developmental delay and mental retardation [23,24]. Patients with DS have an extra copy of chromosome 21, leading to an overproduction of gene products and non-coding RNAs encoded by this chromosome. These include APP, Dual specificity tyrosine-phosphorylation-regulated kinase $1 \mathrm{~A}$ (DYRK1A), runt-related transcription factor 1 (RUNX1), and other chromosome 21-encoded components [23]. Over-production/accumulation of A $\beta$ (a proteolytic product of APP) in the brain is considered as a key factor in AD pathogenesis. Similarly, all DS patients develop an AD-like neuropathology by the age of 40 , including extracellular amyloid plaques, intracellular neurofibrillary tangles and synaptic dysfunction. Endocytic dysfunction is an early pathological event in Alzheimer's disease (AD) and Down's syndrome (DS). In previous studies, investigators found that both primary fibroblasts from DS individuals and neurons from DS mouse models exhibit abnormal endocytic and lysosomal trafficking $[25,26]$. Although several chromosome 21-encoded products such as APP and synaptojanin 1 (SYNJ1) are thought to contribute to these defects $[26,27]$, the detailed molecular mechanisms by which trisomy 21 results in dysfunction of the endocytic trafficking remains largely unclear.

Parkinson's disease (PD), the second most common neurodegenerative disease, affects more than 4 million people worldwide. PD is characterized by a series of motor symptoms, including akinesia, rigidity, postural disturbance and tremor [28]. Motor deficits associated with PD result from the loss of dopaminergic neurons in the substantia nigra subregion of the midbrain. Inherited genetic mutation and environmental toxins have both been reported to be causal to dopaminergic neuronal death. Although most PD patients arise from sporadic cases, less than $10 \%$ of familial cases are caused by single monogenic mutations [29]. Several causative mutations have been identified in rare inherited familial PD [30,31]. For example, autosomal dominantly inherited mutations in $\alpha$-synuclein ( $\alpha$-syn), including missense mutations and triplication of the $\alpha$-synuclein locus, are found in familial forms of inherited PD. Autosomal dominantly inherited mutations in leucine-rich repeat kinase-2 (LRRK2) gene are associated with an increased risk of PD. LRRK2 is a member of the leucine-rich repeat kinase family with GTPase and kinase activities. How these components contribute to PD neuropathology in a protein trafficking context is described below.

\section{Endocytic sorting in neurodegenerative diseases}

Full-length APP is a type I transmembrane protein synthesized in the endoplasmic reticulum (ER) and subsequently transported to TGN [32,33]. APP can be delivered from the TGN to the cell surface where it is cleaved by $\alpha$-secretase to generate a neuroprotective, non-amyloidogenic sAPP $\alpha$ fragment [34]. Several ADAM (a disintegrin and metalloproteinase) family members possess $\alpha$-secretase activity and three ADAMfamily $\alpha$-secretases have been confirmed so far: ADAM9, ADAM10, and ADAM17. APP can also be re-internalized via an endosomal/lysosomal degradation pathway [35]. The neurotoxic $A \beta$ peptide is generated through sequential cleavage by $\beta$-secretase (BACE1) and the $\mathrm{PS} 1 / \gamma$-secretase complex in the ER, Golgi/TGN [33] as well as the endosomal/lysosomal system [36,37]. As the subcellular distribution of APP plays a key role in $A \beta$ generation, delineation of the mechanisms involved in APP trafficking is thus relevant and crucial to understanding the pathogenesis of $\mathrm{AD}$.

Several PD-linked mutations have been found to be associated with LRRK2 and $\alpha$-synuclein genes, and both LRRK 2 and $\alpha$-synuclein have been reported to play important roles in protein sorting in neurons. For instance, PD-associated LRRK2 mutations are implicated in protein degradation defects in lysosomes, suggesting that LRRK2 may affect delivery of cytosolic proteins and protein aggregates to the lysosome [38-40]. In addition, it has been reported that LRRK2 mutations may also induce Golgi fragmentation [41]. It has also been reported that $\alpha$-synuclein affects dopamine release in dopaminergic neurons, and $\alpha-\mathrm{Syn}^{-/}$mice display altered dopamine release [42]. Furthermore, expression of $\alpha$-syn in yeast and mammalian cells blocks protein transport from the endoplasmic reticulum (ER) to Golgi apparatus [43,44]. Taken together, these findings suggest that defective protein 
transport in intracellular compartments plays a role in PD.

\section{Trafficking components and neurodegeneration The retromer complex, SorLA and GGA1}

The Retromer complex is composed of the vacuolar protein sorting (VPS) trimer core sub-complex (VPS26, VPS29, VPS35) and a membrane-associated sorting nexin (SNX) dimer (SNX1, SNX2, SNX5, SNX6) [45]. The retromer complex has been shown to be important in regulating transmembrane receptor recycling from endosomes to TGN. The SNX dimer is required for the recruitment of the retromer complex to the endosomal membrane, and the VPS35 subunit is presumed to be the core cargo-binding component with binds a variety of cargo proteins [46], including CI-M6PR [47], wntless [48-50] and sortilin [51].

Expression of two components of the retromer complex, VPS26 and VPS35, is reduced in the brains of individuals with $\mathrm{AD}$ [52]. Cell culture studies showed that over-expression of VPS35 down-regulated A $\beta$ generation, and VPS35 depletion using small interfering RNAs up-regulated $A \beta$ peptide levels [52]. Further studies revealed that retromer deficiency promotes $A \beta$ generation and exacerbates neurodegeneration by modulating BACE1 activity in Vps26 and Vps35 knockout mouse models $[18,19]$. Moreover, recent research indicates that a chemical chaperone can decrease APP processing and A $\beta$ generation through stabilizing the retromer complex and hence transporting APP away from endosomes [53].

Recently, a missense mutation in the VPS35 subunit (D620N) has been identified in multiple families with late-onset Parkinson's disease (PD) [54-56]. Further mechanistic studies revealed that the VPS35 D620N mutation may redistribute retromer-positive endosomes to a perinuclear subcellular localization. In support of this notion, enlarged endosomes have been found in the fibroblasts isolated from a PD patient with the D620N mutation [57]. Moreover, over-expression of a VPS35 D620N mutant construct disrupts the trafficking of cathepsin D [57], the main lysosomal enzyme for degrading $\alpha$-synuclein [58]. This may suggest that the late-onset PD linked VPS35 D620N mutation leads to endosomal alterations and trafficking defects in patient fibroblasts. The generation of a Vps35 D620N knock-in mouse model and patient-derived induced pluripotent stem (iPS) cell models may provide new strategies to better understand the relevance and mode of action of the D620N VPS35 PD allele.

The Sortilin-related receptor with A-type repeats SorLA (also known as SORL1, LR11) is a type I membrane protein. Reduced SorLA expression has been found in the brains of AD patients [59] and some inherited variants of the SorLA gene have been found to associate with lateonset $\mathrm{AD}$ [60]. Although the function of SorLA in AD pathology is unclear yet, it has been reported that SorLA is involved in APP processing. SorLA modulates recycling of APP and prevents amyloidogenic processing of APP as down-regulation of SorLA increases sorting of APP into A $\beta$-generating compartments [60], while SorLA-deficient mice show increased levels of $A \beta$ [61]. Further, SorLA may regulate APP sorting and processing through interactions with the VPS26 subunit of the retromer complex [62]; VPS26 binding to a cytosolic SORLA tail motif may be important for SorLA-mediated APP retention at the Golgi. Disruption of these interactions results in APP sorting to non-Golgi compartments and increased amyloidogenic APP processing [62]. Recently, the A $\beta$ peptide has been shown to interact directly with the SorLA Vps10 domain, which then directs the $A \beta$ peptide to the lysosome for consequent clearance and degradation [63]. Together, these results indicated that SorLA is an important trafficking component of APP, and may have dual functions in retaining APP at the Golgi, regulating amyloidogenic APP processing and directing the $A \beta$ to lysosomal compartments for subsequent degradation.

ADP-ribosylation factor-binding proteins (GGAs) are a family of Golgi-localized monomeric clathrin adaptor proteins that are involved in the transport of cargo proteins from the TGN to the endosome [64]. Mammalian GGAs (GGA1, GGA2, and GGA3) contain three domains, including a N-terminal VHS domain, an intermediary GAT (GGA and Tom1) domain and a C-terminal GAE ( $\gamma$-adaptin ear) domain [64].

The GGA VHS domain can recognize a BACE1 DISLL motif located within the BACE1 cytoplasmic domain (aa 496-500) $[10,65]$. Previous studies indicate that phosphorylation of BACE1 is important for GGA1-mediated BACE1 endosomal trafficking; phosphorylated BACE1 can be efficiently transported from endosomes to TGN, whereas non-phosphorylated BACE1 is recycled directly from endosomes to the plasma membrane [65-67]. Overexpression of GGA1 reduces A $\beta$ secretion, while knockdown of GGA1 increases A $\beta$ secretion in HEK293 cells [66]. In addition, it has been shown that only GGA1 but not GGA2 and GGA3 can regulate intracellular distribution of SorLA and APP in the endocytic recycling compartments [68]. BACE1 S498A mutation enhances BACE1 targeting to SorLA-positive compartments and attenuates SorLA-mediated reduction of $A \beta$ [68]. However, unlike GGA1, it has been found that GGA3 mediates trafficking of BACE1 to lysosomes for degradation [13,69,70]. It has been reported that ubiquitination of BACE1 at K501 is important for GGA3-mediated BACE1 trafficking to lysosomes and BACE1 stability [71]. In support of this, downregulation of GGA3 increases BACE1 expression [13,70]. In $\mathrm{AD}$ brains, GGA3 level is markedly down-regulated and negatively correlates with BACE1 expression levels. Recently, it has been reported that a small GTPase ADP 
ribosylation factor 6 (ARF6) is important for regulating the internalization of BACE1 into early endosomes to promote BACE1-mediated APP cleavage. To facilitate this process, the BACE1 DISLL motif is required for BACE1 sorting from ARF6-positive endosomes to RAB5-positive endosomes [72].

\section{Sorting nexins in APP processing and synaptic dysfunction}

The sorting nexin family of trafficking components comprise 33 family members, each containing a signature lipid-binding PX domain [73]. At least 5 sorting nexins have been found to regulate APP cleavage or A $\beta$ production (Figure 1). Sorting nexin 17 (SNX17) was the first identified sorting nexin in the regulation of APP trafficking and processing [74]. In early endosomes, SNX17 regulates APP endocytosis through specific binding to the YXNPXY motif in the APP cytoplasmic domain. SNX17 loss-of-function through over-expression of a dominantnegative mutant of SNX17 or siRNA knockdown of SNX17 in human glioblastoma U87 cells reduced steadystate APP levels and increased $A \beta$ production. In addition, SNX17 can regulate cell surface delivery of LRP by promoting its recycling from early endosomes [75]. The FERM domain and the carboxyl-terminal region of SNX17 is required for LRP binding, and SNX17 binds to the cytoplasmic tail NPxY motif of LRP. Functional mutation of the NPxY motif reduced LRP recycling from endosomes but did not influence LRP endocytosis. Likewise, knockdown of SNX17 using siRNA also disrupted LRP recycling.
SNX33 was identified as a new activator of APP $\alpha$ secretase cleavage [76]. Over-expression of SNX33 in cultured HEK293 and COS cells markedly increased APP $\alpha$-secretase cleavage but did not affect on $\beta$-secretase cleavage. SNX33 has been found to bind the endocytic GTPase component dynamin to reduce APP endocytosis in a dynamin-dependent manner. Increased cell surface expression of APP results in enhanced $\alpha$-cleavage upon SNX33 over-expression. It is anticipated that future studies will investigate SNX33 loss-of-function and its effect on APP processing.

Using a tandem affinity purification-based proteomic approach, SNX6 was identified as a BACE1-associated protein [77]. Interestingly, SNX6 is a putative component of the retromer complex. Knockdown of SNX6 increased generation of $\beta$-cleavage products of APP, including $A \beta$, sAPP $\beta$ and $\beta$-CTF. Furthermore, reduction of SNX6 stabilized BACE1 and promoted retrograde transport of BACE1 from the cell surface to perinuclear vesicles.

SNX12 is highly expressed in brain tissues and is mainly localized in early endosomes [78]. Over-expression of SNX12 reduced A $\beta$ levels, soluble APP $\beta$ and APP $\beta$ carboxyl terminal fragments, but did not affect steadystate levels of APP, BACE1 or $\gamma$-secretase components [79]. Conversely, down-regulation of SNX12 by siRNA transfection reverses these effects. Modulation of SNX12 levels has little or no effect on $\gamma$-secretase activity or in vitro $\beta$-secretase activity. Further studies reveal that SNX12 interacts with BACE1 and down-regulation of SNX12 accelerates BACE1 endocytosis and decreases steady-state cell surface BACE1 levels. Importantly,

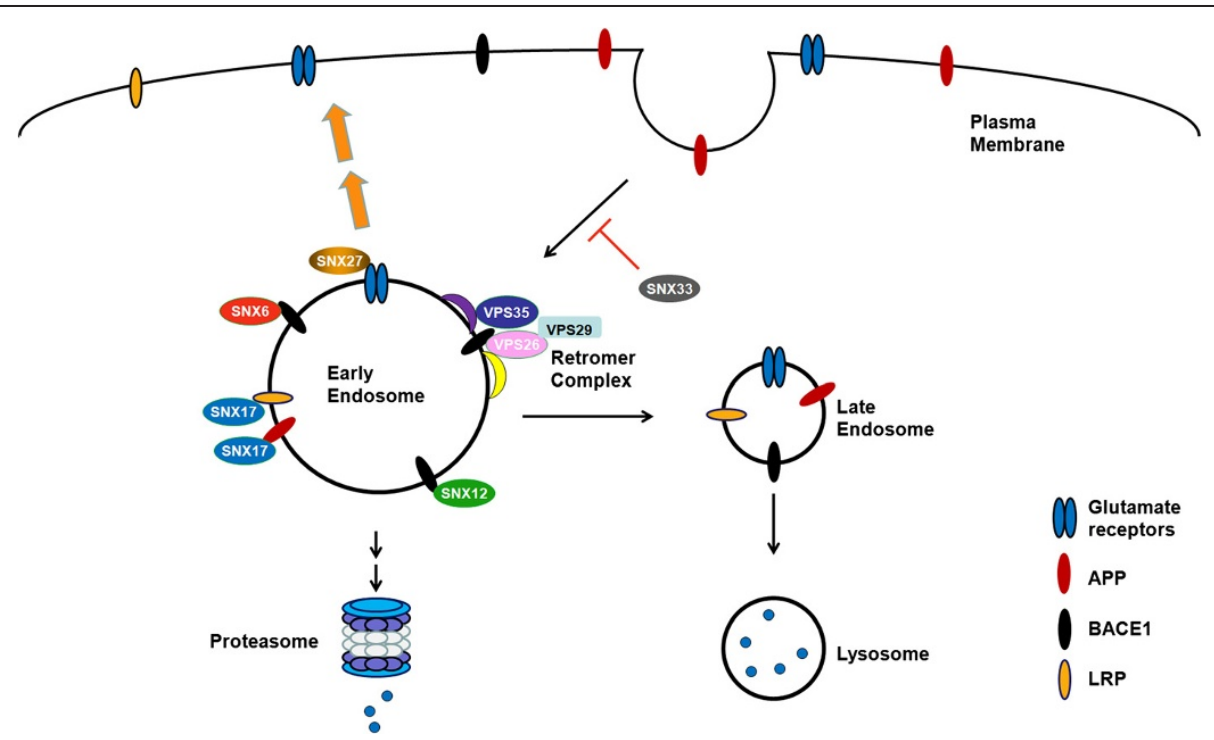

Figure 1 Regulation of AD-associated proteins by sorting nexins and the retromer complex. SNX6, SNX12, SNX17 and SNX27 regulate cell surface delivery of several AD-associated proteins, including APP, BACE1, glutamate receptors and LRP. SNX33 inhibits APP endocytosis in a dynamin-dependent manner. Over-expression of SNX33 up-regulates cell surface APP levels and increases a-secretase cleavage of APP. The retromer complex regulates APP processing and A $\beta$ generation through modulating BACE1 trafficking and activity. 
SNX12 protein levels are markedly reduced in human brain tissue from sporadic AD patients.

SNX27 is a brain-enriched sorting nexin component, and is the only sorting nexin family member containing a PDZ domain. Snx27 is essential for normal development and survival in mammals, as $S n \times 27^{-1}$ mice display developmental retardation phenotypes [80] and severe neuronal pathology in the hippocampus and cortex [81]. $\operatorname{Sn} \times 27^{+/-}$mice comprise a normal neuroanatomy overall, but demonstrate defects in synaptic function, learning and memory accompanied with a reduction in the ionotropic NMDA and AMPA class glutamate receptors. SNX27 interacts with these receptors through its PDZ domain $[81,82]$, regulating their recycling to the plasma membrane. Interestingly, reduced expression of SNX27 and its upstream regulatory transcription factor CCAAT/ enhancer binding protein $\beta(C / E B P \beta)$ has been observed in Down syndrome brains. Over-expression of the chromosome 21-encoded microRNA, miR-155 in trisomy 21 results in the attenuation of C/EBP $\beta$ expression, thereby reducing SNX27 levels, resulting in concomitant synaptic dysfunction. Restoration of SNX27 in the hippocampus of Ts65Dn Down syndrome mouse models rescues synaptic and cognitive deficits. In addition to its role in synaptic function, we also found that SNX27 deficiency enhances $\mathrm{PS} 1 / \gamma$-secretase complex formation and increases $\gamma$-secretase abundance and activity to elevate $\mathrm{A} \beta$ production both in vitro and in vivo (unpublished data).

\section{Mint family and Ras-related GTP-binding (Rab) proteins}

The Mint (Munc18 interacting protein, also known as X11) adaptor protein family includes three members: neuron specific Mint1 and Mint2, and the ubiquitously expressed Mint3 [83,84]. All three Mint proteins consist of a phosphotyrosine binding (PTB) domain and two tandem PDZ (postsynaptic density-95/discs large/zona occludens-1) domains. Evidence so far indicates that the Mint family is involved in neuronal protein transport and synaptic function [85-87]. Mint proteins can interact with the APP C-terminus (YENPTY motif) through the PTB domain binding. APP interaction with mint proteins has been found to influence APP trafficking/processing and $A \beta$ generation in vitro and in vivo [87-89]. In addition, Mint1 and Mint2 have been reported to bind to presenilin1 through their PDZ domains $[90,91]$ and Mint proteins potentially inhibit $\gamma$-secretase-mediated APP cleavage through direct interactions. However, a detailed mechanism how this occurs is yet lacking.

Several Rab GTPase components have been found to regulate APP processing and $A \beta$ production. Rab1B plays a key role in the transport of APP or APP $\beta$-CTF from the endoplasmic reticulum to the Golgi; expression of a dominant-negative mutant of the Rab1B almost completely eliminates $A \beta$ generation [92,93]. Rab6 is involved in intra-Golgi vesicular trafficking and a Rab6 N126I dominant negative mutant has been found to enhance amyloidogenic APP processing [94]. It has been recently shown that $\mathrm{EH}$ domain-containing proteins (EHDs) and Rab11 facilitate BACE1 trafficking in dendrites and axons in primary neurons [95-97]. Several Rab proteins have been reported to be involved in PS1mediated protein trafficking, such as Rab11 [98], Rab6 [99] and Rab GDP dissociation inhibitor [100].

Enlarged early endosomes, increased immunoreactivity for early endosome markers (rab5, EEA1 and rabaptin5), and the recycling endosome marker rab4 have been observed in the neurons of a Ts65Dn DS mouse model [26]. In addition, increased endocytic uptake, fusion, and recycling have also been found in DS human fibroblasts. Moreover, DS fibroblasts show an increased number of enlarged endosomal vesicles enriched with the late endosome marker rab7 [25]. These changes strikingly resemble neurons from both $\mathrm{AD}$ and DS brains. Interestingly, over-expression of a rab5 mutant that inhibits endocytic uptake reversed endosomal abnormalities in DS fibroblasts.

Recently, it has been reported that deficiency of the PARK16 locus gene RAB7L1 is involved in PD neuropathology. RAB7L1 over-expression rescues LRRK2 mutationinduced phenotypes in a drosophila PD model [101]. Expression of the VPS35 retromer component could rescue the endosomal-lysosomal sorting defects caused by mutant LRRK2 or RAB7L1 in vitro and in vivo [101]. Together, these results indicate that various trafficking components such as RAB7L1 and VPS35 can exert protective effects on pathological PD components such as LRKK2.

\section{The roles of PS1 in autophagy}

Autophagy is a catabolic pathway triggered by starvation and involves degradation of cellular components through the lysosome. Autophagy is involved in eliminating damaged organelles and misfolded protein aggregates, and removes unnecessary cellular components to liberate available nutrients during starvation. As an essential process in neuronal survival, dysfunction in the autophagic response has been found to contribute to neurodegeneration. It has been reported that the AD-related protein PS1 is required for autophagy [102,103], and loss of PS1 can result in impaired proteolytic activation and autophagosome clearance. Familial AD-associated PS1 mutations commonly found in early-onset AD may affect lysosomal function and accelerate neurodegenerative progression $[104,105]$. Defective lysosomal proteolysis may trigger accumulation of toxic proteins and cause neuronal cell death in $\mathrm{AD}$ and other neurodegenerative diseases. However, the mechanisms underlying these processes remain controversial. Lee et al. found that deficits in the 
autophagy pathway may be caused by impaired PS1dependent delivery of the v-ATPase V0a1 subunit to lysosomes, thereby attenuating autolysosome acidification and cathepsin activation [106]. Coen et al. showed that Nglycosylation may not be necessary for targeting and normal function of the V-ATPase subunit, and that defective $\mathrm{N}$-glycosylation of $\mathrm{VOa} 1$ and lysosomal acidification may not be the cause of endo-lysosomal dysfunction in PS1/2 dKO cells. Rather, a disruption in lysosomal calcium storage and release was found to be impaired in PS1/2 dKO cells, thereby contributing to autophagic defects [107]. In addition, transcriptome analysis of PS1/2 dKO mouse brains revealed a role for presenilins in regulating lysosomal biogenesis [108]. Although how presenilins are involved in autophagic processes in neurodegeneration remains unclear at this point, new aspects of presenilins in autophagy will be surely uncovered in future studies.

\section{Conclusion}

Although endocytic trafficking has been well-studied in the last few decades, regulation of protein trafficking in the context of neurodegenerative diseases is far from clear. For example, as a well-characterized substrate of $\alpha$-, $\beta$ - and $\gamma$-secretases, APP and its metabolites play a critical role in AD pathology. Cumulative evidence demonstrates that APP cleavage by different secretases may occur at distinct subcellular compartments, implicating the importance of the subcellular distribution of APP and various secretases in regulating $A \beta$ generation. Trafficking regulation in neurodegenerative diseases is a complicated process in which a number of regulators, motor molecules and membrane proteins are involved. Despite the characterization of several common defects in protein sorting and neuropathology found in DS and AD so far, further studies are anticipated to uncover unique trafficking pathways for DS and AD. In addition, future studies are needed to determine how PD-associated gene mutations can affect membrane vesicle trafficking, and more importantly vesicular trafficking of neurotransmitters to cause dopaminergic dysfunction. This review covers some aspects of endocytic trafficking regulation in several disease-associated proteins, including APP, secretases, glutamate receptors and LRRK2. Future research is expected to strengthen our understanding of dysregulated protein trafficking in neurodegeneration and may potentially provide new prevention or treatment strategies.

\section{Abbreviations}

A $\beta$ : $\beta$-amyloid; AD: Alzheimer's disease; ADAM: A Disintegrin and Metalloprotease; AICD: APP intracellular domain; APP: Amyloid beta (A4) precursor protein; ARF6: ADP ribosylation factor 6; BACE1: Beta-site APP-cleaving enzyme 1; C/EBP $\beta$ : CCAAT/enhancer-binding protein beta; CD-M6PR: Cation-dependent mannose-6-phosphate receptor; CTF: Carboxyl-terminal fragment; DS: Down syndrome; EHDs: EH domaincontaining proteins; ER: Endoplasmic reticulum; GAE: $\gamma$-adaptin ear; GGA: Golgi-localised $\gamma$-adaptin ear-containing ADP ribosylation factor-binding proteins; LRRK2: Leucine-rich repeat kinase 2; LRP1: Low-density lipoprotein receptor-related proteins 1; Mint: Munc18 interacting protein;

NFTs: Neurofibrillary tangles; NTF: Amino-terminal fragment; PDZ: PSD-95, Drosophila disks-large, ZO-1; PLD1: Phospholipase D1; PS1: Presenilin 1; PTB: Phosphotyrosine binding; Rab: Ras-related GTP-binding protein; SNX: Sorting nexin; SORLA: Sortilin-related receptor, (LDLR class) A repeats containing; TGN: Trans-Golgi network; VPS: Vacuolar protein sortingassociated protein; VHS domain: VPS-27, Hrs and STAM domain.

\section{Competing interests}

The authors declare that they have no competing interests.

\section{Authors' contributions}

XW, TH and HX wrote and revised, and GB discussed and revised the manuscript. All authors read and approved the final manuscript.

\section{Acknowledgements}

This work was supported by grants from the National Institutes of Health (R01 AG038710, R01 AG021173, R01 NS046673, R01 AG030197 and R01 AG044420), the Alzheimer's Association and the Global Down Syndrome Foundation (DSADIIP-13-283543). National Natural Science Foundation of China (81225008, 81161120496, 91332112 and 91332114), the Fundamental Research Funds for the Central Universities of China, and Fok Ying Tung Education Foundation.

Received: 29 July 2014 Accepted: 14 August 2014

Published: 25 August 2014

\section{References}

1. Goate A, Chartier-Harlin MC, Mullan M, Brown J, Crawford F, Fidani L, Giuffra L, Haynes A, Irving N, James L, Mant R, Newton P, Rooke K, Roques P, Talbot C, Pericak-Vance M, Roses A, Williamson R, Rossor M, Owen M, Hardy J: Segregation of a missense mutation in the amyloid precursor protein gene with familial Alzheimer's disease. Nature 1991, 349(6311):704-706.

2. Levy-Lahad E, Wasco W, Poorkaj P, Romano DM, Oshima J, Pettingell WH, Yu CE, Jondro PD, Schmidt SD, Wang K: Candidate gene for the chromosome 1 familial Alzheimer's disease locus. Science 1995, 269(5226):973-977.

3. Sherrington R, Rogaev El, Liang $Y$, Rogaeva EA, Levesque $G$, Ikeda M, Chi $H_{\text {, }}$ Lin C, Li G, Holman K, Tsuda T, Mar L, Foncin JF, Bruni AC, Montesi MP, Sorbi S, Rainero I, Pinessi L, Nee L, Chumakov I, Pollen D, Brookes A, Sanseau P, Polinsky RJ, Wasco W, Da Silva HA, Haines JL, Perkicak-Vance $M A$, Tanzi RE, et al: Cloning of a gene bearing missense mutations in early-onset familial Alzheimer's disease. Nature 1995, 375(6534):754-760.

4. Zhang YW, Thompson R, Zhang H, Xu H: APP processing in Alzheimer's disease. Molecular brain 2011, 4:3.

5. Gendron TF, Petrucelli L: The role of tau in neurodegeneration. Mol Neurodegener 2009, 4:13.

6. Selkoe DJ: The cell biology of beta-amyloid precursor protein and presenilin in Alzheimer's disease. Trends Cell Biol 1998, 8(11):447-453.

7. Evin G, Weidemann A: Biogenesis and metabolism of Alzheimer's disease Abeta amyloid peptides. Peptides 2002, 23(7):1285-1297.

8. Yang LB, Lindholm K, Yan R, Citron M, Xia W, Yang XL, Beach T, Sue L, Wong P, Price D, Li R, Shen Y: Elevated beta-secretase expression and enzymatic activity detected in sporadic Alzheimer disease. Nat Med 2003, 9(1):3-4.

9. Spoelgen R, von Arnim CA, Thomas AV, Peltan ID, Koker M, Deng A, Irizarry $M C$, Andersen OM, Willnow TE, Hyman BT: Interaction of the cytosolic domains of sorLA/LR11 with the amyloid precursor protein (APP) and beta-secretase beta-site APP-cleaving enzyme. J Neurosci 2006, 26(2):418-428.

10. He X, Chang WP, Koelsch G, Tang J: Memapsin 2 (beta-secretase) cytosolic domain binds to the VHS domains of GGA1 and GGA2: implications on the endocytosis mechanism of memapsin 2. FEBS Lett 2002, 524(1-3):183-187.

11. Santosa C, Rasche $S$, Barakat A, Bellingham SA, Ho M, Tan J, Hill AF, Masters CL, McLean C, Evin G: Decreased expression of GGA3 protein in Alzheimer's disease frontal cortex and increased co-distribution of BACE with the amyloid precursor protein. Neurobiol Dis 2011, 43(1):176-183. 
12. Finan GM, Okada $H$, Kim TW: BACE1 retrograde trafficking is uniquely regulated by the cytoplasmic domain of sortilin. J Biol Chem 2011, 286(14):12602-12616.

13. Tesco G, Koh YH, Kang EL, Cameron AN, Das S, Sena-Esteves M, Hiltunen M, Yang SH, Zhong Z, Shen Y, Simpkins JW, Tanzi RE: Depletion of GGA3 stabilizes BACE and enhances beta-secretase activity. Neuron 2007, 54(5):721-737.

14. Vassar R, Bennett BD, Babu-Khan S, Kahn S, Mendiaz EA, Denis P, Teplow DB, Ross S, Amarante P, Loeloff R, Luo Y, Fisher S, Fuller J, Edenson S, Lile J, Jarosinski MA, Biere AL, Curran E, Burgess T, Louis JC, Collins F, Treanor J, Rogers G, Citron M: Beta-secretase cleavage of Alzheimer's amyloid precursor protein by the transmembrane aspartic protease BACE. Science 1999, 286(5440):735-741.

15. Hook VY, Toneff T, Aaron W, Yasothornsrikul S, Bundey R, Reisine T: Beta-amyloid peptide in regulated secretory vesicles of chromaffin cells: evidence for multiple cysteine proteolytic activities in distinct pathways for beta-secretase activity in chromaffin vesicles. J Neurochem 2002 81(2):237-256.

16. Huse JT, Pijak DS, Leslie GJ, Lee VM, Doms RW: Maturation and endosomal targeting of beta-site amyloid precursor protein-cleaving enzyme. The Alzheimer's disease beta-secretase. J Biol Chem 2000, 275(43):33729-33737.

17. Sullivan CP, Jay AG, Stack EC, Pakaluk M, Wadlinger E, Fine RE, Wells JM, Morin PJ: Retromer disruption promotes amyloidogenic APP processing. Neurobiol Dis 2011, 43(2):338-345.

18. Wen L, Tang FL, Hong Y, Luo SW, Wang CL, He W, Shen C, Jung JU, Xiong F, Lee DH, Zhang QG, Brann D, Kim TW, Yan R, Mei L, Xiong WC: VPS35 haploinsufficiency increases Alzheimer's disease neuropathology. J Cell Biol 2011, 195(5):765-779.

19. Muhammad A, Flores I, Zhang H, Yu R, Staniszewski A, Planel E, Herman M, Ho L, Kreber R, Honig LS, Ganetzky B, Duff K, Arancio O, Small SA: Retromer deficiency observed in Alzheimer's disease causes hippocampal dysfunction, neurodegeneration, and Abeta accumulation. Proc Natl Acad Sci U S A 2008, 105(20):7327-7332.

20. Pietrzik CU, Busse T, Merriam DE, Weggen S, Koo EH: The cytoplasmic domain of the LDL receptor-related protein regulates multiple steps in APP processing. EMBO J 2002, 21(21):5691-5700.

21. Trommsdorff M, Borg JP, Margolis B, Herz J: Interaction of cytosolic adaptor proteins with neuronal apolipoprotein $E$ receptors and the amyloid precursor protein. J Biol Chem 1998, 273(50):33556-33560.

22. Kounnas MZ, Moir RD, Rebeck GW, Bush Al, Argraves WS, Tanzi RE, Hyman BT, Strickland DK: LDL receptor-related protein, a multifunctional ApoE receptor, binds secreted beta-amyloid precursor protein and mediates its degradation. Cell 1995, 82(2):331-340.

23. Dierssen M: Down syndrome: the brain in trisomic mode. Nat Rev Neurosci 2012, 13(12):844-858.

24. Haydar TF, Reeves RH: Trisomy 21 and early brain development. Trends Neurosci 2012, 35(2):81-91.

25. Cataldo AM, Mathews PM, Boiteau AB, Hassinger LC, Peterhoff CM, Jiang $Y$, Mullaney K, Neve RL, Gruenberg J, Nixon RA: Down syndrome fibroblast model of Alzheimer-related endosome pathology: accelerated endocytosis promotes late endocytic defects. Am J Pathol 2008, 173(2):370-384.

26. Cataldo AM, Petanceska S, Peterhoff CM, Terio NB, Epstein CJ, Villar A, Carlson EJ, Staufenbiel M, Nixon RA: App gene dosage modulates endosomal abnormalities of Alzheimer's disease in a segmental trisomy 16 mouse model of down syndrome. J Neurosci 2003, 23(17):6788-6792.

27. Cossec JC, Lavaur J, Berman DE, Rivals I, Hoischen A, Stora S, Ripoll C, Mircher C, Grattau Y, Olivomarin JC, de Chaumont F, Lecourtois M, Antonarakis SE, Veltman JA, Delabar JM, Duyckaerts C, Di Paolo G, Potier MC: Trisomy for synaptojanin 1 in down syndrome is functionally linked to the enlargement of early endosomes. Hum Mol Genet 2012, 21(14):3156-3172.

28. Dauer W, Przedborski S: Parkinson's disease: mechanisms and models. Neuron 2003, 39(6):889-909.

29. Trinh J, Farrer M: Advances in the genetics of Parkinson disease. Nat Rev Neurol 2013, 9(8):445-454.

30. Abeliovich A, Flint Beal M: Parkinsonism genes: culprits and clues. J Neurochem 2006, 99(4):1062-1072.

31. Hardy J, Cai H, Cookson MR, Gwinn-Hardy K, Singleton A: Genetics of Parkinson's disease and parkinsonism. Ann Neurol 2006, 60(4):389-398.

32. Xu H, Sweeney D, Wang R, Thinakaran G, Lo AC, Sisodia SS, Greengard P, Gandy S: Generation of Alzheimer beta-amyloid protein in the trans-Golgi network in the apparent absence of vesicle formation. Proc Natl Acad Sci US A 1997, 94(8):3748-3752.

33. Greenfield JP, Tsai J, Gouras GK, Hai B, Thinakaran G, Checler F, Sisodia SS, Greengard P, Xu H: Endoplasmic reticulum and trans-Golgi network generate distinct populations of Alzheimer beta-amyloid peptides. Proc Natl Acad Sci U S A 1999, 96(2):742-747.

34. Sisodia SS: Beta-amyloid precursor protein cleavage by a membrane-bound protease. Proc Natl Acad Sci U S A 1992, 89(13):6075-6079.

35. Caporaso GL, Takei K, Gandy SE, Matteoli M, Mundigl O, Greengard P, De Camilli P: Morphologic and biochemical analysis of the intracellular trafficking of the Alzheimer beta/A4 amyloid precursor protein. J Neurosci 1994, 14(5 Pt 2):3122-3138.

36. Haass C, Hung AY, Schlossmacher MG, Teplow DB, Selkoe DJ: beta-Amyloid peptide and a 3-kDa fragment are derived by distinct cellular mechanisms. J Biol Chem 1993, 268(5):3021-3024

37. Haass C, Hung AY, Schlossmacher MG, Oltersdorf T, Teplow DB, Selkoe DJ: Normal cellular processing of the beta-amyloid precursor protein results in the secretion of the amyloid beta peptide and related molecules. Ann N Y Acad Sci 1993, 695:109-116.

38. MacLeod D, Dowman J, Hammond R, Leete T, Inoue K, Abeliovich A: The familial Parkinsonism gene LRRK2 regulates neurite process morphology. Neuron 2006, 52(4):587-593.

39. Heo HY, Kim KS, Seol W: Coordinate Regulation of Neurite Outgrowth by LRRK2 and Its Interactor, Rab5. Experiment Neurobiol 2010, 19(2):97-105.

40. Dodson MW, Zhang T, Jiang C, Chen S, Guo M: Roles of the Drosophila LRRK2 homolog in Rab7-dependent lysosomal positioning. Hum Mol Genet 2012, 21(6):1350-1363.

41. Stafa K, Trancikova A, Webber PJ, Glauser L, West AB, Moore DJ: GTPase activity and neuronal toxicity of Parkinson's disease-associated LRRK2 is regulated by ArfGAP1. PLOS Genet 2012, 8(2):e1002526.

42. Abeliovich A, Schmitz Y, Farinas I, Choi-Lundberg D, Ho WH, Castillo PE, Shinsky N, Verdugo JM, Armanini M, Ryan A, Hynes M, Phillips H, Sulzer D, Rosenthal A: Mice lacking alpha-synuclein display functional deficits in the nigrostriatal dopamine system. Neuron 2000, 25(1):239-252.

43. Cooper AA, Gitler AD, Cashikar A, Haynes CM, Hill KJ, Bhullar B, Liu K, Xu K, Strathearn KE, Liu F, Cao S, Caldwell KA, Caldwell GA, Marsischky G, Kolodner RD, Labaer J, Rochet JC, Bonini NM, Lindquist S: Alpha-synuclein blocks ER-Golgi traffic and Rab1 rescues neuron loss in Parkinson's models. Science 2006, 313(5785):324-328.

44. Thayanidhi N, Helm JR, Nycz DC, Bentley M, Liang Y, Hay JC: Alphasynuclein delays endoplasmic reticulum (ER)-to-Golgi transport in mammalian cells by antagonizing ER/Golgi SNAREs. Mol Biol Cell 2010, 21(11):1850-1863.

45. Seaman MN: Recycle your receptors with retromer. Trends Cell Biol 2005, 15(2):68-75

46. Seaman MN: Cargo-selective endosomal sorting for retrieval to the Golgi requires retromer. J Cell Biol 2004, 165(1):111-122.

47. Seaman MN: Identification of a novel conserved sorting motif required for retromer-mediated endosome-to-TGN retrieval. J Cell Sci 2007, 120(Pt 14):2378-2389.

48. Belenkaya TY, Wu Y, Tang X, Zhou B, Cheng L, Sharma YV, Yan D, Selva EM, $L$ in $X$ : The retromer complex influences $W n t$ secretion by recycling wntless from endosomes to the trans-Golgi network. Dev Cell 2008, 14(1):120-131.

49. Yang PT, Lorenowicz MJ, Silhankova M, Coudreuse DY, Betist MC, Korswagen $\mathrm{HC}$ : Wnt signaling requires retromer-dependent recycling of MIG-14/Wntless in Wnt-producing cells. Dev Cell 2008, 14(1):140-147.

50. Pan CL, Baum PD, Gu M, Jorgensen EM, Clark SG, Garriga G: C. elegans AP-2 and retromer control Wnt signaling by regulating mig-14/Wntless. Dev Cell 2008, 14(1):132-139.

51. Kim E, Lee $Y$, Lee HJ, Kim JS, Song BS, Huh JW, Lee SR, Kim SU, Kim SH, Hong Y, Shim I, Chang KT: Implication of mouse Vps26b-Vps29-Vps35 retromer complex in sortilin trafficking. Biochem Biophys Res Commun 2010, 403(2):167-171.

52. Small SA, Kent K, Pierce A, Leung C, Kang MS, Okada H, Honig L, Vonsattel JP, Kim TW: Model-guided microarray implicates the retromer complex in Alzheimer's disease. Ann Neurol 2005, 58(6):909-919.

53. Mecozzi VJ, Berman DE, Simoes S, Vetanovetz C, Awal MR, Patel VM, Schneider RT, Petsko GA, Ringe D, Small SA: Pharmacological chaperones stabilize retromer to limit APP processing. Nat Chem Biol 2014, 10(6):443-449. 
54. Zimprich A, Benet-Pages A, Struhal W, Graf E, Eck SH, Offman MN, Haubenberger D, Spielberger S, Schulte EC, Lichtner P, Rossle SC, Klopp N, Wolf E, Seppi K, Pirker W, Presslauer S, Mollenhauer B, Katzenschlager R, Foki T, Hotzy C, Reinthaler E, Harutyunyan A, Kralovics R, Peters A, Zimprich F, Brücke T, Poewe W, Auff E, Trenkwalder C, Rost B, et al: A mutation in VPS35, encoding a subunit of the retromer complex, causes late-onset Parkinson disease. Am J Hum Genet 2011, 89(1):168-175.

55. Vilarino-Guell C, Wider C, Ross OA, Dachsel JC, Kachergus JM, Lincoln SJ, Soto-Ortolaza Al, Cobb SA, Wilhoite GJ, Bacon JA, Behrouz B, Melrose HL, Hentati E, Puschmann A, Evans DM, Conibear E, Wasserman WW, Aasly JO, Burkhard PR, Djaldetti R, Ghika J, Hentati F, Krygowska-Wajs A, Lynch T, Melamed E, Rajput A, Rajput AH, Solida A, Wu RM, Uitti RJ, et al: VPS35 mutations in Parkinson disease. Am J Hum Genet 2011, 89(1):162-167.

56. Ando M, Funayama M, Li Y, Kashihara K, Murakami Y, Ishizu N, Toyoda C, Noguchi K, Hashimoto T, Nakano N, Sasaki R, Kokubo Y, Kuzuhara S, Ogaki K, Yamashita C, Yoshino H, Hatano T, Tomiyama H, Hattori N: VPS35 mutation in Japanese patients with typical Parkinson's disease. Mov Disord 2012, 27(11):1413-1417.

57. Follett J, Norwood SJ, Hamilton NA, Mohan M, Kovtun O, Tay S, Zhe Y, Wood SA, Mellick GD, Silburn PA, Collins BM, Bugarcic A, Teasdale RD: The Vps35 D620N mutation linked to Parkinson's disease disrupts the cargo sorting function of retromer. Traffic 2014, 15(2):230-244.

58. Sevlever D, Jiang P, Yen SH: Cathepsin D is the main lysosomal enzyme involved in the degradation of alpha-synuclein and generation of its carboxy-terminally truncated species. Biochemistry 2008, 47(36):9678-9687.

59. Scherzer CR, Offe K, Gearing M, Rees HD, Fang G, Heilman CJ, Schaller C, Bujo H, Levey Al, Lah JJ: Loss of apolipoprotein E receptor LR11 in Alzheimer disease. Arch Neurol 2004, 61(8):1200-1205.

60. Rogaeva E, Meng Y, Lee JH, Gu Y, Kawarai T, Zou F, Katayama T, Baldwin CT, Cheng $\mathrm{R}$, Hasegawa $\mathrm{H}$, Chen $\mathrm{F}$, Shibata $\mathrm{N}$, Lunetta KL, Pardossi-Piquard R, Bohm C, Wakutani Y, Cupples LA, Cuenco KT, Green RC, Pinessi L, Rainero I, Sorbi S, Bruni A, Duara R, Friedland RP, Inzelberg R, Hampe W, Bujo H, Song YQ, Andersen OM, et al: The neuronal sortilin-related receptor SORL1 is genetically associated with Alzheimer disease. Nat Genet 2007, 39(2):168-177.

61. Andersen OM, Reiche J, Schmidt V, Gotthardt M, Spoelgen R, Behlke J, von Arnim CA, Breiderhoff T, Jansen P, Wu X, Bales KR, Cappai R, Masters CL, Gliemann J, Mufson EJ, Hyman BT, Paul SM, Nykjaer A, Willnow TE: Neuronal sorting protein-related receptor sorLA/LR11 regulates processing of the amyloid precursor protein. Proc Natl Acad Sci U S A 2005, 102(38):13461-13466.

62. Fjorback AW, Seaman M, Gustafsen C, Mehmedbasic A, Gokool S, Wu C, Militz D, Schmidt V, Madsen P, Nyengaard JR, Willnow TE, Christensen El, Mobley WB, Nykjær A, Andersen OM: Retromer binds the FANSHY sorting motif in SorLA to regulate amyloid precursor protein sorting and processing. J Neurosci 2012, 32(4):1467-1480.

63. Caglayan S, Takagi-Niidome S, Liao F, Carlo AS, Schmidt V, Burgert T, Kitago Y, Fuchtbauer EM, Fuchtbauer A, Holtzman DM, Takagi J, Willnow TE: Lysosomal sorting of amyloid-beta by the SORLA receptor is impaired by a familial Alzheimer's disease mutation. Sci Transl Med 2014, 6(223):223. ra220.

64. Bonifacino JS: The GGA proteins: adaptors on the move. Nat Rev Mol Cell Biol 2004, 5(1):23-32

65. He X, Li F, Chang WP, Tang J: GGA proteins mediate the recycling pathway of memapsin 2 (BACE). J Biol Chem 2005, 280(12):11696-11703.

66. Wahle T, Thal DR, Sastre M, Rentmeister A, Bogdanovic N, Famulok M, Heneka MT, Walter J: GGA1 is expressed in the human brain and affects the generation of amyloid beta-peptide. J Neurosci 2006, 26(49):12838-12846.

67. Wahle T, Prager K, Raffler N, Haass C, Famulok M, Walter J: GGA proteins regulate retrograde transport of $B A C E 1$ from endosomes to the trans-Golgi network. Mol Cell Neurosci 2005, 29(3):453-461.

68. Herskowitz JH, Offe K, Deshpande A, Kahn RA, Levey Al, Lah JJ: GGA1-mediated endocytic traffic of LR11/SorLA alters APP intracellular distribution and amyloid-beta production. Mol Biol Cell 2012, 23(14):2645-2657.

69. Haass C, Kaether C, Thinakaran G, Sisodia S: Trafficking and proteolytic processing of APP. Cold Spring Harb Perspect Med 2012, 2(5):a006270.

70. Natunen T, Parrado AR, Helisalmi S, Pursiheimo JP, Sarajarvi T, Makinen P, Kurkinen KM, Mullin K, Alafuzoff I, Haapasalo A, Bertram L, Soininen H, Tanzi RE,
Hiltunen M: Elucidation of the BACE1 regulating factor GGA3 in Alzheimer's disease. J Alzheimers Dis 2013, 37(1):217-232.

71. Kang EL, Biscaro B, Piazza F, Tesco G: BACE1 protein endocytosis and trafficking are differentially regulated by ubiquitination at lysine 501 and the Di-leucine motif in the carboxyl terminus. J Biol Chem 2012, 287(51):42867-42880.

72. Sannerud R, Declerck I, Peric A, Raemaekers T, Menendez G, Zhou L, Veerle B, Coen K, Munck S, De Strooper B, Schiavo G, Annaert W: ADP ribosylation factor 6 (ARF6) controls amyloid precursor protein (APP) processing by mediating the endosomal sorting of BACE1. Proc Natl Acad Sci U S A 2011, 108(34):E559-E568.

73. Cullen PJ: Endosomal sorting and signalling: an emerging role for sorting nexins. Nat Rev Mol Cell Biol 2008, 9(7):574-582.

74. Lee J, Retamal C, Cuitino L, Caruano-Yzermans A, Shin JE, van Kerkhof P, Marzolo MP, Bu G: Adaptor protein sorting nexin 17 regulates amyloid precursor protein trafficking and processing in the early endosomes. J Biol Chem 2008, 283(17):11501-11508.

75. van Kerkhof P, Lee J, McCormick L, Tetrault E, Lu W, Schoenfish M, Oorschot V, Strous GJ, Klumperman J, Bu G: Sorting nexin 17 facilitates LRP recycling in the early endosome. EMBO J 2005, 24(16):2851-2861.

76. Schobel S, Neumann S, Hertweck M, Dislich B, Kuhn PH, Kremmer E, Seed B, Baumeister R, Haass C, Lichtenthaler SF: A novel sorting nexin modulates endocytic trafficking and alpha-secretase cleavage of the amyloid precursor protein. J Biol Chem 2008, 283(21):14257-14268.

77. Okada H, Zhang W, Peterhoff C, Hwang JC, Nixon RA, Ryu SH, Kim TW: Proteomic identification of sorting nexin 6 as a negative regulator of BACE1-mediated APP processing. FASEB J 2010, 24(8):2783-2794.

78. Mizutani R, Nakamura K, Kato N, Aizawa K, Miyamoto Y, Torii T, Yamauchi J, Tanoue A: Expression of sorting nexin 12 is regulated in developing cerebral cortical neurons. J Neurosci Res 2012, 90(4):721-731.

79. Zhao Y, Wang Y, Yang J, Wang X, Zhao Y, Zhang X, Zhang YW: Sorting nexin 12 interacts with BACE1 and regulates BACE1-mediated APP processing. Mol Neurodegener 2012, 7:30.

80. Cai L, Loo LS, Atlashkin V, Hanson BJ, Hong W: Deficiency of sorting nexin 27 (SNX27) leads to growth retardation and elevated levels of $\mathrm{N}$ methyl-D-aspartate receptor 2C (NR2C). Mol Cell Biol 2011, 31(8):1734-1747.

81. Wang X, Zhao Y, Zhang X, Badie H, Zhou Y, Mu Y, Loo LS, Cai L, Thompson RC, Yang B, Chen Y, Johnson PF, Wu C, Bu G, Mobley WC, Zhang D, Gage FH, Ranscht B, Zhang YW, Lipton SA, Hong W, Xu H: Loss of sorting nexin 27 contributes to excitatory synaptic dysfunction by modulating glutamate receptor recycling in Down's syndrome. Nat Med 2013, 19(4):473-480.

82. Loo LS, Tang N, Al-Haddawi M, Dawe GS, Hong W: A role for sorting nexin 27 in AMPA receptor trafficking. Nat Commun 2014, 5:3176

83. Okamoto M, Sudhof TC: Mints, Munc18-interacting proteins in synaptic vesicle exocytosis. J Biol Chem 1997, 272(50):31459-31464.

84. Okamoto M, Sudhof TC: Mint 3: a ubiquitous mint isoform that does not bind to munc18-1 or -2. Eur J Cell Biol 1998, 77(3):161-165.

85. Rogelj B, Mitchell JC, Miller CC, McLoughlin DM: The X11/Mint family of adaptor proteins. Brain Res Rev 2006, 52(2):305-315.

86. Biederer T, Cao X, Sudhof TC, Liu X: Regulation of APP-dependent transcription complexes by Mint/X11s: differential functions of Mint isoforms. J Neurosci 2002, 22(17):7340-7351.

87. King GD, Perez RG, Steinhilb ML, Gaut JR, Turner RS: X11alpha modulates secretory and endocytic trafficking and metabolism of amyloid precursor protein: mutational analysis of the YENPTY sequence. Neuroscience 2003, 120(1):143-154.

88. Borg JP, Yang Y, De Taddeo-Borg M, Margolis B, Turner RS: The X11alpha protein slows cellular amyloid precursor protein processing and reduces Abeta40 and Abeta42 secretion. J Biol Chem 1998, 273(24):14761-14766.

89. Ho A, Liu X, Sudhof TC: Deletion of Mint proteins decreases amyloid production in transgenic mouse models of Alzheimer's disease. J Neurosci 2008, 28(53):14392-14400.

90. Lau KF, McLoughlin DM, Standen C, Miller CC: X11 alpha and $\mathrm{x} 11$ beta interact with presenilin-1 via their PDZ domains. Mol Cell Neurosci 2000, 16(5):557-565.

91. King GD, Cherian K, Turner RS: X11alpha impairs gamma- but not beta-cleavage of amyloid precursor protein. J Neurochem 2004, 88(4):971-982.

92. Dugan JM, de Wit C, McConlogue L, Maltese WA: The Ras-related GTP-binding protein, Rab1B, regulates early steps in exocytic transport and processing of beta-amyloid precursor protein. J Biol Chem 1995, 270(18):10982-10989. 
93. Maltese WA, Wilson $S$, Tan $Y$, Suomensaari $S$, Sinha $S$, Barbour R, McConlogue L: Retention of the Alzheimer's amyloid precursor fragment C99 in the endoplasmic reticulum prevents formation of amyloid beta-peptide. J Biol Chem 2001, 276(23):20267-20279.

94. McConlogue L, Castellano F, de Wit C, Schenk D, Maltese WA: Differential effects of a Rab6 mutant on secretory versus amyloidogenic processing of Alzheimer's beta-amyloid precursor protein. J Biol Chem 1996, 271(3):1343-1348.

95. Buggia-Prevot V, Fernandez CG, Udayar V, Vetrivel KS, Elie A, Roseman J, Sasse VA, Lefkow M, Meckler X, Bhattacharyya S, George M, Kar S, Bindokas VP, Parent AT, Rajendran L, Band H, Vassar R, Thinakaran G: A function for EHD family proteins in unidirectional retrograde dendritic transport of BACE1 and Alzheimer's disease Abeta production. Cell reports 2013, 5(6):1552-1563.

96. Udayar V, Buggia-Prevot V, Guerreiro RL, Siegel G, Rambabu N, Soohoo AL, Ponnusamy M, Siegenthaler B, Bali J, AESG Simons M, Ries J, Puthenveedu MA, Hardy J, Thinakaran G, Rajendran L: A paired RNAi and RabGAP overexpression screen identifies Rab11 as a regulator of beta-amyloid production. Cell reports 2013, 5(6):1536-1551.

97. Buggia-Prevot V, Fernandez CG, Riordan S, Vetrivel KS, Roseman J, Waters J, Bindokas VP, Vassar R, Thinakaran G: Axonal BACE1 dynamics and targeting in hippocampal neurons: a role for Rab11 GTPase. Mol Neurodegener 2014, 9:1.

98. Dumanchin C, Czech C, Campion D, Cuif MH, Poyot T, Martin C, Charbonnier F, Goud B, Pradier L, Frebourg T: Presenilins interact with Rab11, a small GTPase involved in the regulation of vesicular transport. Hum Mol Genet 1999, 8(7):1263-1269.

99. Scheper W, Zwart R, Baas F: Rab6 membrane association is dependent of Presenilin 1 and cellular phosphorylation events. Brain Res Mol Brain Res 2004, 122(1):17-23.

100. Scheper W, Zwart R, Sluijs P, Annaert W, Gool WA, Baas F: Alzheimer's presenilin 1 is a putative membrane receptor for rab GDP dissociation inhibitor. Hum Mol Genet 2000, 9(2):303-310.

101. MacLeod DA, Rhinn H, Kuwahara T, Zolin A, Di Paolo G, McCabe BD, Marder KS, Honig LS, Clark LN, Small SA, Abeliovich A: RAB7L1 interacts with LRRK2 to modify intraneuronal protein sorting and Parkinson's disease risk. Neuron 2013, 77(3):425-439.

102. Wilson CA, Murphy DD, Giasson Bl, Zhang B, Trojanowski JQ, Lee VM: Degradative organelles containing mislocalized alpha-and beta-synuclein proliferate in presenilin-1 null neurons. J Cell Biol 2004, 165(3):335-346.

103. Esselens $C$, Oorschot V, Baert V, Raemaekers T, Spittaels K, Serneels $L$, Zheng H, Saftig P, De Strooper B, Klumperman J, Annaert W: Presenilin 1 mediates the turnover of telencephalin in hippocampal neurons via an autophagic degradative pathway. J Cell Biol 2004, 166(7):1041-1054.

104. Cataldo AM, Peterhoff CM, Schmidt SD, Terio NB, Duff K, Beard M, Mathews PM, Nixon RA: Presenilin mutations in familial Alzheimer disease and transgenic mouse models accelerate neuronal lysosomal pathology. J Neuropathol Exp Neurol 2004, 63(8):821-830.

105. Nixon RA: The role of autophagy in neurodegenerative disease. Nat Med 2013, 19(8):983-997.

106. Lee JH, Yu WH, Kumar A, Lee S, Mohan PS, Peterhoff CM, Wolfe DM, Martinez-Vicente M, Massey AC, Sovak G, Uchiyama Y, Westaway D, Cuervo AM, Nixon RA: Lysosomal proteolysis and autophagy require presenilin 1 and are disrupted by Alzheimer-related PS1 mutations. Cell 2010, 141(7):1146-1158.

107. Coen K, Flannagan RS, Baron S, Carraro-Lacroix LR, Wang D, Vermeire W, Michiels C, Munck S, Baert V, Sugita S, Wuytack F, Hiesinger PR, Grinstein S, Annaert W: Lysosomal calcium homeostasis defects, not proton pump defects, cause endo-lysosomal dysfunction in PSEN-deficient cells. J Cell Biol 2012, 198(1):23-35.

108. Zhang X, Garbett K, Veeraraghavalu K, Wilburn B, Gilmore R, Mirnics K, Sisodia SS: A role for presenilins in autophagy revisited: normal acidification of lysosomes in cells lacking PSEN1 and PSEN2. J Neurosci 2012, 32(25):8633-8648.

doi:10.1186/1750-1326-9-31

Cite this article as: Wang et al: Dysregulation of protein trafficking in neurodegeneration. Molecular Neurodegeneration 2014 9:31.

\section{Submit your next manuscript to BioMed Central and take full advantage of:}

- Convenient online submission

- Thorough peer review

- No space constraints or color figure charges

- Immediate publication on acceptance

- Inclusion in PubMed, CAS, Scopus and Google Scholar

- Research which is freely available for redistribution

Submit your manuscript at www.biomedcentral.com/submit
() Biomed Central 